\title{
THE TEMPERATURE ACTIVATION OF CARBON SATURATION STEEL PROCESS
}

\author{
Katarzyna Szota \\ Institute of Mathematics, Czestochowa University of Technology \\ Częstochowa, Poland \\ katarzyna.szota@im.pcz.pl
}

\begin{abstract}
The study presents the application of a mathematical description of a thermochemical process which consists in diffusion saturation of steel with carbon atoms. The mathematical description assumes temperature-based activation of the process of carburizing and estimates the effect of diffusion flow, which has a direct effect on the thickness of the obtained carburized layers, on the process temperature. The assumed model can be universal for all thermo-chemical processes of diffusion saturation of metallic materials.
\end{abstract}

Keywords: steel carbonizing process, diffusional saturation, mathematical description

\section{Introduction}

Due to its complexity and parallel changes of many parameters in time, the carburizing process, which has been used for years, is very difficult to be described mathematically in universal terms $[1,2]$.

Carburizing is understood to mean a thermo-chemical process of diffusion saturation of the surface layer of the material. Saturation of a surface layer of steel with carbon atoms is aimed at improving the tribological and corrosion resistance and strength [3].

\section{Carburizing process}

The most popular technique today is carburizing using the gas phase, ion carburizing and liquid carburizing [4]. All the above types of carburizing are diffusion-based processes. A prerequisite for diffusion is the generation of carburizing atmosphere, with its carbon potential being higher than unity, i.e. the atmosphere should be saturated with carbon atoms higher than carbon content present in the carburized material. The thickness of the carburized layer is determined chiefly by carburizing time and temperature of the carburized material [5-7]. For most steels, gas carburizing is carried out at the temperature of $880 \div 920^{\circ} \mathrm{C}$ [6]. Apart from temperature and time, the results of this process are also determined by carbon potential and the flow 
of medium gases termed the diffusion stream, which is formed by the particles of a solid (e.g. sand or $\mathrm{Al}_{2} \mathrm{O}_{3}$ ) maintained in a suspension by a hot saturating gas flowing through a bed from the bottom upwards, the description is presented in Figure 1 [3]. Vacuum saturation ensures better carbon adsorption from the atmosphere with low pressure and lower gas consumption [8].

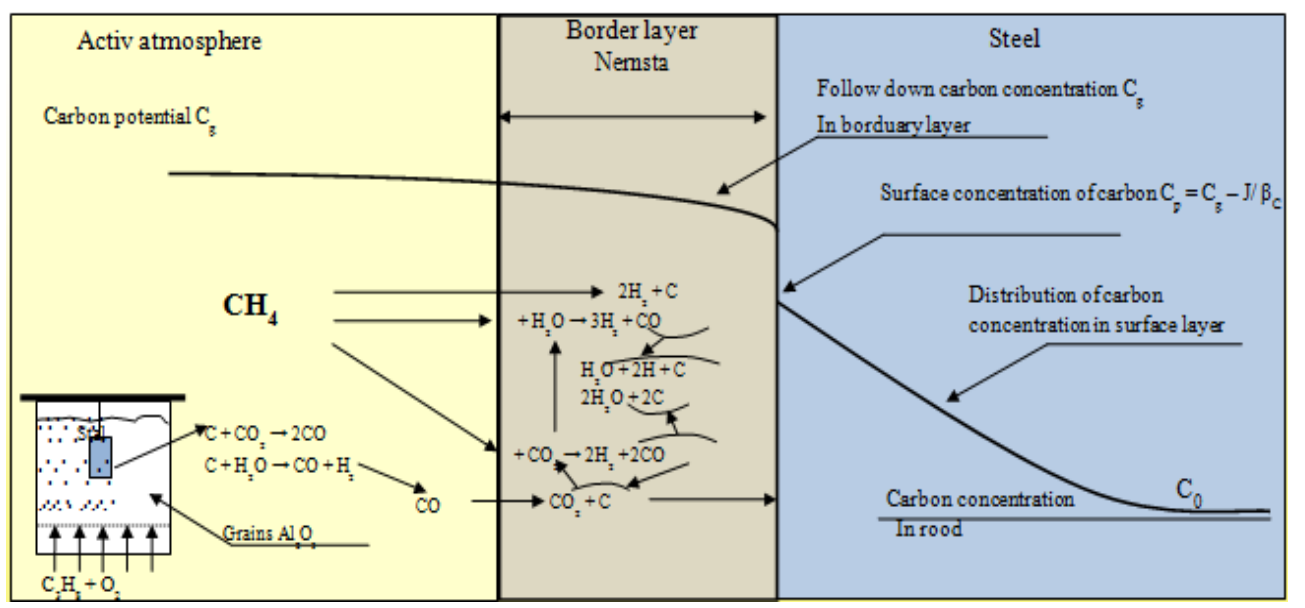

Fig. 1. The description of in situ atmosphere production and carbon atoms diffusion to steel during saturation process in fluidized bed

After carbonizing processes there are usually obtained surface layers characterized by distribution of different physical and mechanical properties as the same properties of the materials root. The structural differences after carbon saturation process are presented in Figure 2.

a)
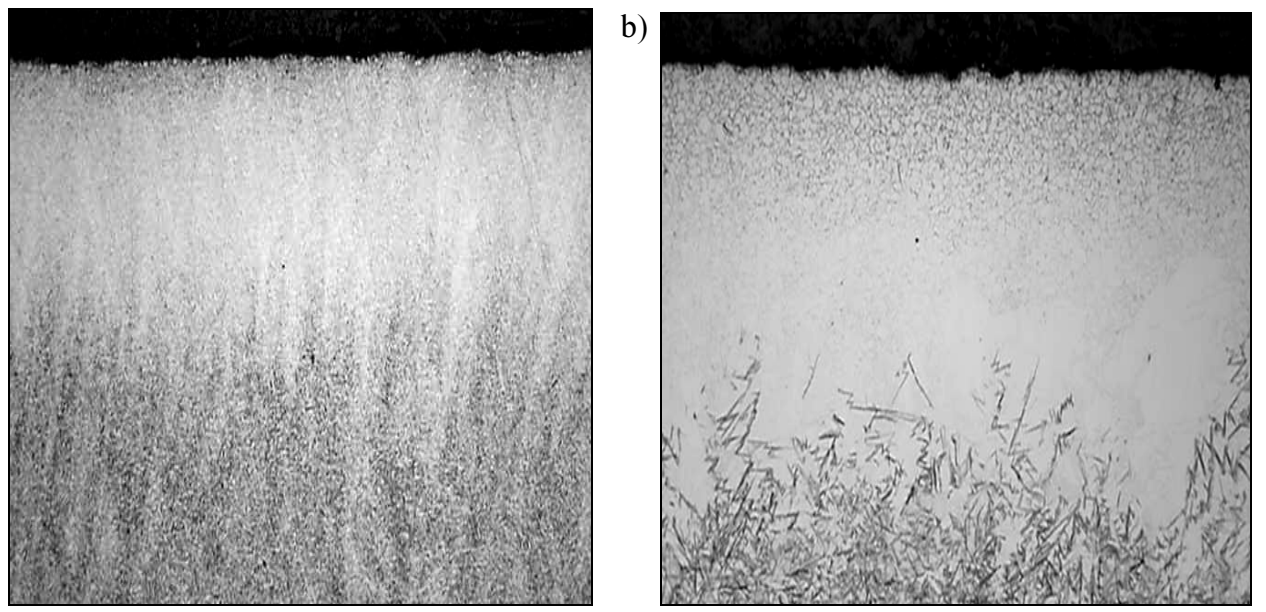

Fig. 2. The samples of microstructure of surface layer steel after carburizing, $\mathrm{T}=1173 \mathrm{~K}$, etched in nital, magn. 50x, a) $\tau=3 \mathrm{~h}, \mathrm{~b}) \tau=12 \mathrm{~h}$ [9] 


\section{Mathematical formulas}

The diffusional saturation process is usually the temperature activate, by oscillation and movement of atoms in the lattice of the metal. A quantitative description of this phenomenon is complex and likely to use many simplifying assumptions. The carbon saturation process is dependent on temperature, time and a concentration of the atoms gradients. These factors have a big influence on material properties such as thickness and the structure of the surface layer, which is obtained by carrying out the carburizing process.

The diffusion processes are described by Fick's laws, because in this process, the stream of atoms diffusion is variable at the time, and is suitable in this case using Fick's second law:

$$
\frac{\partial \Phi}{\partial t}=D \frac{\partial^{2} \Phi}{\partial x^{2}}
$$

where:

$\Phi$ - concentration,

$x$ - distance from the source to the diffusing substance,

$t$ - time.

$D$ is a proportionality coefficient (diffusion constant, this coefficient is connected with the probability of an atom jumping in a crystal lattice)

$$
D=D_{0} e^{-\frac{E_{A}}{k T}}
$$

where:

$E_{A}$ - activation energy,

$k$ - gas constant distance from the source to the diffusing substance,

$T$ - temperature.

Generally, there are three known basic mechanisms of diffusion, which depending on the activation energy occur at the surface, on the grain boundaries or on the bulk. Considering the bulk diffusion, which requires the highest activation energy directional anisotropy present in the crystallographic structure of a solid state should be considered $[9,13]$. This implies that, in practice, diffusion is not a one-direction, mass flow should be considered in three perpendicular directions, then the equation (1) takes the form

$$
\frac{\partial \Phi}{\partial t}=\frac{\partial}{\partial x}\left(D_{x} \frac{\partial \Phi}{\partial x}\right)+\frac{\partial}{\partial y}\left(D_{y} \frac{\partial \Phi}{\partial y}\right)+\frac{\partial}{\partial z}\left(D_{z} \frac{\partial \Phi}{\partial z}\right)
$$

where: $D_{x}, D_{y}, D_{z}$ - directional diffusion coefficients.

In practice, the size of the diffusion coefficient depends on the density of the arrangement of atoms and the symmetry of the lattice. For crystal lattice with a less 
dense arrangement of the value of the energy need to atoms jumping is smaller. In the case when the phenomenon of the diffusion carburizing process relates to metals of regular networks or assumed that the direction diffusional stream is perpendicular to the surface of material then it can be assumed that the coefficient of diffusion is isotropic, so equation (3) can be written as

$$
\frac{\partial \Phi}{\partial t}=D\left(\frac{\partial^{2} \Phi}{\partial x^{2}}+\frac{\partial^{2} \Phi}{\partial y^{2}}+\frac{\partial^{2} \Phi}{\partial z^{2}}\right)
$$

Generally various methods of diffusion activation may be used e.g.: mechanical, chemical and thermal. However, in industrial practice, the most common method of activation is thermal activation of the diffusion. The temperature has a strong influence on activation of diffusion, because usually the result of the temperature increasing is an increase of atoms frequency, with a supply of thermal energy necessary to jump an atom from one lattice node to another. The pressure increase reduces the diffusion coefficient, the density of lattice defects promotes the growth of the diffusion coefficient.

\section{Conclusions}

The analysis presented in the paper represents an introduction to further research into development of a universal mathematical model that describes the diffusion of atoms of saturating elements into metallic materials. The measurable effect of the further research expected by the authors will be the development of computer software which will offer real-time support for engineering decisions and be dedicated to the people dealing with the design and supervision of thermal and chemical processes.

\section{References}

[1] Szota M., Jasiński J., Modeling of carbonizing process, Inżynieria Materiałowa 2010, 31, 27-29.

[2] Szota M., Jasiński J., Modeling the carbonized steel $20 \mathrm{HM}$ in fluized bed by means of neutral networks, 4th Youth Imeko Symposium on Experimental Solid Mechanics, Castocaro Therme, Italy $2005,109-111$.

[3] Szota M., Jasiński J., Modeling carbonizing of steel 19 HM in fluized bed by means of neutral networks, Conf. Mat., 4th International Conference Coatings and Layers, Roznow pod Radhostem 2005, 119-121.

[4] Banaszkiewicz J., Kamiński M., Podstawy korozji materiałów, Oficyna Wydawnicza Politechniki Warszawskiej, Warszawa 1997.

[5] Blicharski M., Przemiany fazowe, AGH, Kraków 1990.

[6] Blicharski M., Inżynieria materiałowa: stal, WNT, Warszawa 2004.

[7] Dobrzański L.A., Podstawy nauki o materiałach i metaloznawstwo, WNT, Warszawa 2003.

[8] Szota M., Modelowanie nawęglania stali w złożu fluidalnym, rozprawa doktorska, 2008. 
[9] Szota M., Jasiński J., Using neural networks application for prediction of parameters of carbonizing process in fluidized bed, Inżynieria Materiałowa 2008, 6, 877-880.

[10] Jasiński J., Torbus R., Szota M., Struktura warstwy wierzchniej po dyfuzyjnym nasycaniu aktywowanej powierzchni, Inżynieria Materiałowa 2008.

[11] Smoljan B., Smokvina Hanza S., Tomašić N., Iljkić D., Computer simulation of microstructure transformation in heat treatment process, Journal of Achievements in Materials and Manufacturing Engineering 2007, 24, I, 275-282.

[12] Pernach M., Numeryczne rozwiązanie równania dyfuzji z ruchomą powierzchnią międzyfazową do modelowania przemiany austenit - ferryt, rozprawa doktorska, AGH 2007.

[13] Dobrzański L.A., Kształtowanie struktury i właściwości powierzchni materiałów inżynierskich i biomedycznych, Prace Instytutu Materiałów Inżynierskich i Biomedycznych Politechniki Śląskiej, Gliwice 2009. 